\title{
Agri-food commodity mapping and trade between Indonesia and Australia
}

\author{
Syahrul Ganda Sukmaya ${ }^{1, *}$, Saptana ${ }^{2}$, and Atika Dyah Perwita ${ }^{3}$ \\ ${ }^{1}$ Universitas Jenderal Soedirman, Faculty of Agriculture, Purwokerto 53122, Indonesia \\ ${ }^{2}$ Indonesian Centre for Agricultural Socio Economic and Policy Studies, Bogor, 16124, Indonesia \\ ${ }^{3}$ State Islamic University of Walisongo, Semarang, 50185, Indonesia
}

\begin{abstract}
This article investigates the dynamics of comparative advantage and trade performance in agri-food items between Indonesia and Australia. The method used in this study is to measure comparative advantage and export performance from 2000 to 2019 using balassa index (BI), Lafay index (LFI), and trade balance index (TBI). The findings show that Indonesia significantly reported negative TBI in trading both with the world and Australia, using a 'products mapping' methodology focused on trade balance index (TBI), Balassa index (BI), Lafay index (LFI), and other descriptive approaches. According to the results of both BI and LFI, Indonesia has a high rate of unfavorable TBI in total food items, both globally and in Australia, indicating that the nation has depended heavily on food imports for home use. Indonesia's competitive advantage in trade with Australia was 9/31 food items, according to the product mapping. Indonesia has competitive disadvantages and a negative TBI in 9/31 food items traded with Australia. Indonesia urgently needs to increase investment and enforce policies on domestic agriculture and food value chains to improve its exports and competitiveness, especially in products with natural advantages.
\end{abstract}

\section{Introduction}

After about ten years of negotiations, the typical average time for trade negotiations, Indonesia and Australia have reached an agreement on the bilateral economic agreement's effective date of entry into force. This arrangement does not just address trade problems; it also considers long-term investment, so it is called a comprehensive economic cooperation agreement. Since Indonesia joined the reform, economic ties between thetwo countries have grown stronger, beginning with more official visits and conversations [1].In 2010, Indonesia and Australia started discussing the possibility of concluding a straight bilateral agreement as a precursor to the Free Trade Area (AANZFTA).

The anticipation and enthusiasm for this bilateral have increased in the lead-up to July 2020. Indonesia and Australia are the Cairns Group, APEC, RCEP, and the East Asia Summit. However, both countries lack bilateral economic cooperation and need to establish

* Corresponding author : syahrul.ganda@unsoed.ac.id 
development program frameworks and trade agreements, despite their shared goal for trade and investment cooperation. Along with this requirement, the world has become increasingly interested in broad bilateral economic cooperation. In 2010, the CPTPP and the RCEP ushered in a new era of bilateralism to counter mega regionalism. Bilateral CEPA becomes the most viable option for two countries wanting to expand economic relations from trade to investment without giving in to international pressure.

Before the entry into force of the IA-CEPA, Indonesia had concluded bilateral trade agreements with Japan (IJEPA), Pakistan (IPPTA), and Chile (CEPA). In contrast to the PTA, bilateral CEPA agreements include both goods and services trade and long-term investment partnerships. Economic evaluations must consider commercial connections and indications of commerce; other forms of central economic cooperation, such as foreign direct investment, may also be evaluated [2]. Indonesia needs broader bilateral economic cooperation, and Australia is an ideal partner. While international economic relations include both trade and investment, the agreement may focus only on business (PTA and FTA) or on bothbusiness and investment (EPA and CEPA).

Historically, agricultural trade patterns and specialization have been described in nations and regions' competitive or comparative advantages [3-5]. Recently, several researchers have utilized the comparative advantage method to examine the performance of food items in the marketplace and their competitiveness [6-10]. Fertö [5], for example, used the Balassa method to examine the evolution of Central European nations' agri-food trading patterns. The findings indicate that In Czechia, Hungary, Slovenia, Poland, and Lithuania, trade patterns have converged through time, while in Slovakia, Latvia, and Estonia, trade patterns have polarized. Bojnec and Fertő [10], in a similar vein, analyze competitiveness in food trade between EU member states. The findings indicate that the EU member states have increased their food industry competitiveness. Benesova et al. [8] examine the agricultural sector's performance in Russia. Their results show the Russian agri-food product had comparative advantages development countries such as Africa and Asia. Rather than that, the nation didn't have competitive advantages in trade with the European Union and the United States. Other research on trade performance in the agricultural sector was conducted by Esquivias [9]. This research analyzed the performance of Indonesia's and East Java's agricultural trade patterns to those of six major ASEAN exporting countries. The agricultural product categories were classified into four distinct quadrants based on their comparative advantage and export specialization using the revealed comparative advantage (RCA) method. The findings indicate that ASEAN countries have a greater degree of competitive advantage and trade specialization than East Java and Indonesia economies.

This study seeks to analyze the export performance of agri-food products between Indonesia and Australia by mapping trade. This was done because the previous research had not sufficiently discussed the export performance and competitiveness of agri-food products. So, your research seeks to bridge that gap.

\section{Methodology}

The method used in this study is to measure comparative advantage and export performance from 2000 to 2019 using balassa index (BI), Lafay index (LFI), and trade balance index (TBI). The data used in this study is trade data sourced from UN COMTRADE. There are 31 agri-food product groups analyzed in this paper-the agri-food products trade code classification used in this article is based on the SITC revision 3. The agri-food product groups are shown in Table 1. 
Table 1. SITC Code, commodity and data source of Indonesian agri-food product groups.

\begin{tabular}{|c|c|c|}
\hline SITC CODE & Commodity & Data Source \\
\hline 001 & Live animals & UNCOMTRADE \\
\hline 011 & Bovine meat & UNCOMTRADE \\
\hline 012 & Other meat, meat offal & UNCOMTRADE \\
\hline 017 & Meat, OFFL. PRPD, PRSVD, NES & UNCOMTRADE \\
\hline 022 & Milk and cream & UNCOMTRADE \\
\hline 023 & Butter, other fat of milk & UNCOMTRADE \\
\hline 024 & Cheese and curd & UNCOMTRADE \\
\hline 034 & Fish, fresh, Chilled, Frozen & UNCOMTRADE \\
\hline 036 & Crustaceans, molluscs etc. & UNCOMTRADE \\
\hline 037 & Fish etc.,. PREPD,PRSVD.NES & UNCOMTRADE \\
\hline 041 & Wheat, meslin, unmilled & UNCOMTRADE \\
\hline 044 & Maize unmilled & UNCOMTRADE \\
\hline 048 & Cereal preparations & UNCOMTRADE \\
\hline 054 & Vegetables & UNCOMTRADE \\
\hline 056 & Vegetables, PRPD, PRSVD, NES & UNCOMTRADE \\
\hline 057 & Fruit, nuts excl.oil nuts & UNCOMTRADE \\
\hline 058 & Fruit, preserved, prepared & UNCOMTRADE \\
\hline 059 & Fruit, vegetable juices & UNCOMTRADE \\
\hline 061 & Sugars, molasses, honey & UNCOMTRADE \\
\hline 062 & Sugar confectionery & UNCOMTRADE \\
\hline 071 & Coffee, Coffee substitute & UNCOMTRADE \\
\hline 072 & Cocoa & UNCOMTRADE \\
\hline 073 & Chocolate, oth.cocoapreparations & UNCOMTRADE \\
\hline 074 & Tea and mate & UNCOMTRADE \\
\hline 075 & Spices & UNCOMTRADE \\
\hline 091 & Margarine and shortening & UNCOMTRADE \\
\hline 098 & Edible product preparations, nes & UNCOMTRADE \\
\hline 122 & Tobacco, manufactured & UNCOMTRADE \\
\hline 411 & Animals oils and fats & UNCOMTRADE \\
\hline 421 & Fixed Veg. fat, oils, soft & UNCOMTRADE \\
\hline 431 & Animal, Veg. fats,oils, nes. & UNCOMTRADE \\
\hline
\end{tabular}

Source: [20] 
To accurately evaluate the trade specialization in particular goods, it is necessary to analyze the disclosed comparative advantages of the relevant industries. Balassaproposed the revealed comparative advantage (RCA) index, often known as the Balassa index [12,13], to do this (BI). The following formula represents the BI:

$$
\mathrm{BI}_{\mathrm{ij}}=\frac{\mathrm{x}_{\mathrm{ij}}}{\mathrm{X}_{\mathrm{i}}} / \frac{\mathrm{x}_{\mathrm{wj}}}{\mathrm{x}_{\mathrm{W}}}
$$

Whereas: $\mathrm{X}$ for exports items, $\mathrm{i}$ for a particular country, $\mathrm{j}$ for a specific product, and $\mathrm{w}$ for the world export. The BI's value ranges from zero (0) to infinity. Values less than one indicate that the product had a competitive disadvantage. It suggests that the country is the net importer of that particular commodity. In contrast, a value greaterthan one indicates that the nation has a competitive advantage for that specific industry.

Due to the BI's limitations, Sanidas and Shin [14] are worth comparing to another index. As a result, the LFI is chosen [15]; unlike the BI, which utilizes just export values, the LFI operates all trade values (export and import value). The following formula represents the LFI:

$$
\operatorname{LFI}_{j}^{i}=100\left\{\frac{x_{i}^{i}-m_{i}^{i}}{x_{j}^{i}+m_{j}^{i}}-\frac{\sum_{j=1}^{N}\left(x_{j}^{i}-m_{j}^{i}\right)}{\sum_{j=1}^{N}\left(x_{j}^{i}+m_{j}^{i}\right)}\right\} \frac{x_{j}^{i}+m_{j}^{i}}{\sum_{i=j}^{N}\left(x_{j}^{i}+m_{j}^{i}\right)}
$$

Where $\mathrm{x}$ and $\mathrm{m}$ represent the export and import values of a particular food product category, zero is the comparative advantage-neutral value. A positive number indicates that a specific industry has a comparative advantage, whereas a negative value indicates a particular food product's disadvantage. A higher index value indicates a greater degree of comparative advantage and specialization [16].

Additionally, the trade balance index (TBI) is used to determine if a country specializes in export (as a net exporter) or import (as a net importer) of a particular set of goods. TBI is stated as follows:

$$
T B I_{j}^{i}=\frac{x_{j}^{i}-m_{j}^{i}}{x_{j}^{i}+m_{j}^{i}}
$$

Where: $T B I_{j}^{\tilde{i}}$ refers to trade balance index of specific country i for certain product j; $x_{j}^{i}$ and $m_{j}^{i}$ relates to exports and imports of certain product products $\mathrm{j}$ by specific nation $\mathrm{i}$, respectively - the values of the index range from negative 1 to positive 1. Exceptionally, the TBI equals negative 1 if a country imports exclusively. On the other side, if a country exclusively exports, the TBI equals positive 1 . If the TBI value of a particular food product is positive, Indonesia is a net exporter of that food commodity. If the value is negative, Indonesia is a net importer of a consumer of the food product category. Similarly, domestic trade balance and global competitiveness are analyzed to determine trade balance and comparative advantage [16]. As a result of combining the LFI and TBI, products mapping is created, which divides a commodity and a country into several categories (Table 2). 
Table 2. Product mapping scheme.

\begin{tabular}{|c|c|c|}
\hline \multicolumn{2}{|c|}{ Trade balance index (TBI) } \\
\hline \multirow{2}{*}{} & TBI $>0$ & TBI $<0$ \\
\hline \multirow{3}{*}{ LFI $>0$} & Group A & Group B \\
\cline { 2 - 3 } & have comparative advantage & have comparative advantage \\
\cline { 2 - 3 } & have export-specialisation (net-exporter) & no export-specialisation (net-importer) \\
\hline \multirow{3}{*}{ LFI $<0$} & Group C & Group D \\
\cline { 2 - 3 } & have comparative disadvantage & have comparative disadvantage \\
\cline { 2 - 3 } & have export-specialisation (net-exporter) & $\begin{array}{c}\text { have expocialisation (net- } \\
\text { exporter) }\end{array}$ \\
\hline
\end{tabular}

LFI: Lafay Index

Source: [16]

\section{Result and report}

From 2000 to 2019, Appendix 1 shows the results of a comparative competitiveness analysis of Indonesia and the rest of the world and Indonesia and Australia, utilizing BI, LFI, and TBI. According to these findings, Indonesian agri-food goods are competitive in the global market based on their export value (BI). This finding is in line with studies from Dewanta et al., Oktavilia et al., Sukmaya, and Saptana [17-19]. This study found that Indonesian agri-food goods are competitive in the global market, such as fish and crustaceans, Fruit, tobacco, and vegetable oils.

When the export and import trade balances are examined (LFI), the competitiveness of Indonesian agri-food goods on the global market is typically neutral (LFI value $=0$ ). This distinction exists because BI assesses a product's competitiveness only based on its export value. At the same time, LFI analyzes the export value and the import value of agri-food goods. Then, based on TBI measures, it was determined that Indonesia is a net importer of agri-food goods into the global market. Meanwhile, the trade relationship between Indonesia and Australia demonstrates that Indonesia has competitive advantages in agrifood goods (LFI). However, given that Indonesia is a net importer of agricultural goods, Indonesia has a trade deficit in agri-food products.

Trade-in agri-food goods between Indonesia and Australia has historically been less lucrative. Australians profit more than Indonesians from agri-food trading. This is evident from the TBI value from 2000 to 2019 (Appendix 2), which is harmful, indicating that Indonesiais a net importer of agri-food items to Australia. Additionally, the number of goods classifiedas group A and group D may be observed. According to Table 4, between 2000 and 2019, the number of Indonesian agri-food commodities classified as group A (having a comparative advantage) has been as little as 4-6 items out of 31 commodities, with sluggish growth. While Indonesia's agri-food commodities are classified as group D (comparative disadvantage), asmany as 21-24 commodities out of 31 were found to be in this category.

Mapping agricultural goods using comparative advantages analysis through BI and LFI (Appendix 3) demonstrates that Indonesia's trading circumstances with Australia are balanced. The balance of Indonesian trade with Australia is shown by the number of competitive agri-food goods and those that are not. There are as many as nine commodities in the group A category (have comparative advantage-net exporter). There are as many as nine goods in the Group D category (have comparative disadvantage-net importers). There are five commodities classified as group B (have comparative advantage-net importers). 
Additionally, eight commodities are classified as group C (have comparative disadvantagenet exporters).

\section{Conclusions}

The results indicate that Indonesia has a high rate of unfavorable TBI in total food items, both globally and in Australia, meaning that the nation has depended heavily on food imports for home use. Indonesia's competitive advantage in trade with Australia was 9/31 food items, according to the product mapping. Indonesia has competitive disadvantages and a negative TBI in 9/31 food items traded with Australia. To increase exports and competitiveness, Indonesia urgently needs to expand investment in domestic agricultural and food value chains, particularly in goods where the nation has comparative advantages. Indonesian authorities should prioritize food items in Group B and C since these products can advance to Group A due to competitive advantages and positive TBI.

\section{References}

1. B. Resosudarmo, K. V.-L., and undefined 2015, Openresearch Repository. Anu. Edu. $\mathrm{Au}$ (n.d.).

2. Y. Fukuoka and K. Verico, 53 (2016).

3. R. Serrano and V. Pinilla, Agribusiness 30, 165 (2014).

4. I. Zdráhal, V. B.-A. U. Agriculturae, and undefined 2018, Pdfs.Semanticscholar.Org (2018).

5. I. Fertõ, Post-Communist Econ. 20, 1 (2008).

6. J. Burianova, A. B.-A. On-line P. in Economics, and undefined 2012, Ageconsearch.Umn.Edu (2012).

7. A. Jambor and S. Babu, Compet. Glob. Agric. 99 (2016).

8. B. Irena, M. Mansoor, S. Lubos, ... T. K.-A., and undefined 2017, Agriculturejournals. $\mathrm{Cz}$ (n.d.).

9. M. E.-A. on-line P. in E. and undefined 2017, Ageconsearch.Umn.Edu 1, 33 (2017).

10. Š. Bojnec and I. Fertő, Post-Communist Econ. 27, 205 (2015).

11. B. Balassa, Manchester Sch. 33, 99 (1965).

12. B. Balassa, Manchester Sch. 45, 327 (1977).

13. E. Sanidas, Y. S.-9th K. and the W. E. Conference, and undefined 2010, Akes. Or. Kr (n.d.).

14. G. Lafay, Int. Trade Model. 209 (1992).

15. A. Zaghini, Econ. Transit. 13, 629 (2005).

16. T. Widodo, (2008).

17. A. Setya Dewanta and R. Noer Arfani, Econ. J. Emerg. Mark. 8, 148 (2016).

18. S. Oktavilia, Firmansyah, F. Sugiyanto, and M. A. Rachman, IOP Conf. Ser. Earth Environ. Sci. 246, 012006 (2019).

19. S. G. Sukmaya and S. Saptana, E3S Web Conf. 232, 02001 (2021).

20. UNCOMTRADE, Int. Trade Stat. (2021). 


\section{Appendix}

Appendix 1. Descriptive statistics (BI, LFI, and TBI Indexes)

\begin{tabular}{|c|c|c|c|c|c|c|c|c|c|c|c|}
\hline & 2000 & 2002 & 2004 & 2006 & 2008 & 2010 & 2012 & 2014 & 2016 & 2018 & 2019 \\
\hline BI (Ina-world) & 1.590 & 1.259 & 1.376 & 1.161 & 1.416 & 1.358 & 1.039 & 1.104 & 1.329 & 1.104 & 1.274 \\
\hline LFI (Ina-world) & 0.000 & 0.000 & 0.000 & 0.000 & 0.000 & 0.000 & 0.000 & 0.000 & 0.000 & 0.000 & 0.000 \\
\hline TBI (Ina-world) & -0.481 & -0.571 & -0.620 & -0.780 & -0.587 & -0.567 & -0.767 & -0.583 & -0.537 & -0.674 & -0.612 \\
\hline LFI (Ina-Aus) & 0.269 & 0.278 & 0.148 & 0.152 & 0.371 & 0.151 & 0.156 & 0.144 & 0.204 & 0.291 & 0.096 \\
\hline TBI (Ina-Aus) & -0.418 & -0.571 & -0.602 & -0.786 & -0.709 & -0.585 & -0.655 & -0.766 & -0.673 & -0.674 & -0.611 \\
\hline
\end{tabular}

Appendix 2. Dynamics of agri-food trade between Indonesia-Australia

\begin{tabular}{|c|c|c|c|c|c|}
\hline Indicators & 2000 & 2005 & 2010 & 2015 & 2019 \\
\hline Number of food Products & 31 & 31 & 31 & 31 & 31 \\
\hline TBI (index) & -0.452 & -0.681 & -0.663 & -0.482 & -0.533 \\
\hline \multicolumn{6}{|c|}{ Product Mapping (LFI) } \\
\hline A (Number of Product) & 6 & 5 & 4 & 5 & 6 \\
\hline A (TBI) & 0.931 & 0.953 & 0.921 & 0.921 & 0.973 \\
\hline B (Number of Product) & 3 & 3 & 3 & 2 & 4 \\
\hline B (TBI) & -0.423 & -0.231 & -0.532 & -0.091 & -0.352 \\
\hline D (Number of Product) & 22 & 23 & 24 & 23 & 21 \\
\hline $\mathrm{D}(\mathrm{TBI})$ & -0.962 & -0.974 & -0.942 & -0.871 & 0.963 \\
\hline
\end{tabular}


Appendix 3. Product mapping (BI and LFI) between Indonesia and Australia, 2000-2019

\begin{tabular}{|c|c|c|c|}
\hline $\begin{array}{c}\text { GROUP A } \\
\text { (Have Comparative } \\
\text { Advantage-Net Exporter) } \\
\text { 9 Commodity }\end{array}$ & $\begin{array}{c}\text { GROUP B } \\
\text { (Have Comparative } \\
\text { Advantage-Net Importer) } \\
\text { 5 Commodity }\end{array}$ & $\begin{array}{c}\text { GROUP C } \\
\text { (Have Comparative } \\
\text { disadvantage-NetExporter) } \\
\text { 8 Commodity }\end{array}$ & $\begin{array}{c}\text { GROUP D } \\
\text { (Have Comparative } \\
\text { disadvantage-NetImporter) } \\
9 \text { Commodity }\end{array}$ \\
\hline $\begin{array}{l}122 \text { Tobacco, manufactured } \\
\text { 098 Edible product preparations, nes } \\
\text { 072 Cocoa } \\
\text { 048 Cereal preparation } \\
\text { 037 Fish etc.PREPD, PRSVD.NES } \\
\text { 034 Fish, fresh, chilled, frozen } \\
\text { 071 Coffee, coffee substitute } \\
\text { 058 Fruit, preserved, prepared } \\
\text { 036 Crustaceans, molluscs, etc. }\end{array}$ & $\begin{array}{l}074 \text { Tea and mate } \\
075 \text { Spices } \\
431 \text { Animal, veg. fats, oils,nes } \\
\text { 062 Sugar confectionery } \\
\text { 056 Vegetables,PRPD,PRSVD,NES }\end{array}$ & $\begin{array}{l}\text { 054 Vegetables } \\
421 \text { Fixed veg. fat,oils,soft } \\
\text { 073 Chocolate,oth.cocoa } \\
\text { Prep.091 Margarine and } \\
\text { shortening023 Butter, other } \\
\text { fat of milk } 411 \text { Animal oils } \\
\text { and fats } \\
\text { 059 Fruit, Vegetable Juices } \\
\text { 044 Maize unmilled }\end{array}$ & $\begin{array}{l}\text { 001 Live animals } \\
011 \text { Bovine meat } \\
041 \text { Wheat, meslin,unmilled } \\
\text { 061 Sugars, molases, honey } \\
\text { 057 Fruit,nuts excl.oil nuts } \\
\text { 012 Other meat, meat offal } \\
\text { 022 Milk and cream } \\
\text { 024 Cheese and curd } \\
\text { 017 Meat,OFFL.PRPD,PRSVD,NES }\end{array}$ \\
\hline
\end{tabular}

